\title{
Causes, Nature and Toxicology of Fentanyl-Analogues Associated Fatalities: A Systematic Review of Case Reports and Case Series
}

\author{
Umaani Rauf(D' \\ Majid $\mathrm{Ali}^{2}$ \\ Inderpal Dehele' \\ Vibhu Paudyal (D)' \\ Mohamed Hassan Elnaem (1D ${ }^{3,4}$ \\ Ejaz Cheema $\mathbb{I D}^{\prime}$
}

'School of Pharmacy, University of Birmingham, Birmingham, BI5 2TT, UK;

${ }^{2}$ Faculty of Health and Medical Sciences, University of Adelaide, Adelaide,

Australia; ${ }^{3}$ Department of Pharmacy

Practice, Faculty of Pharmacy,

International Islamic University Malaysia, Kuantan, Pahang, Malaysia; ${ }^{4}$ Quality Use of Medicines Research Group, Faculty of Pharmacy, International Islamic University Malaysia, Kuantan, Pahang, Malaysia
Correspondence: Ejaz Cheema

School of Pharmacy, University of

Birmingham, Edgbaston, Birmingham, BI5

2TT, UK

Tel +44 I2I-4I 46845

Email E.Cheema@bham.ac.uk
Objective: Mortalities due to fentanyl derivatives are on the rise with novel fentanyl analogues and still emerging on the global illicit drug market. They are highly potent and very fatal in low doses, yet there has been a lack of systematic research surrounding this subject. This review aims to assess the causes, nature, and toxicology of fatalities associated with fentanyl analogues.

Methods: Five databases: Scopus, Embase, Medline, PubMed and Google Scholar were searched from inception to October 2020 to identify case studies and case series reporting fentanyl analogue-related fatalities. Two independent reviewers screened and selected the articles followed by the data extraction from each article, which included demography, route of administration, causes and nature of death, and the fentanyl analogue implicated. All articles were then subject to quality assessment tools developed by the Joanna Briggs Institute (JBI). A narrative synthesis was undertaken.

Results: The initial data search yielded 834 articles, only 14 of which met the inclusion criteria - this included nine case reports and five case series. Of the 1079 fentanyl-analogue related deaths reported, the majority of them occurred in the US ( $n=1044,96.8 \%)$. The majority of fatalities were male $(n=766,71 \%)$, white $(n=884,87 \%)$ and in the age ranges $25-$ 34 and $35-44$ years $(30.5 \%$ and $29.6 \%$, respectively). The most common route of administration was intravenous $(n=319,66 \%)$ and the manner of death was almost exclusively accidental (99.7\%). The predominant cause of death was fentanyl-analogue toxicity $(n=292,85.4 \%)$ and involved mixed drug toxicity $(n=47,13.7 \%)$. The mean post-mortem fentanyl analogue concentration was $31.6 \mathrm{ng} / \mathrm{mL}$.

Conclusion: Most fatalities were reported in the US involving young white males. Overdose through intravenous administration and by mixed drug toxicities with other opioids were the major causes of death. Deaths reported in peer-reviewed literature were relatively less than those reported by real-world data.

Keywords: fentanyl-analogues, fatalities, systematic review, case series, case reports

\section{Introduction}

Fentanyl and its analogues are synthetic opioid analgesics which act as full agonists for the $\mu$-opioid receptor. ${ }^{1}$ Fentanyl itself is 50-100 times more potent than morphine and one of its analogues, carfentanil, is estimated to be 10,000 times more potent. ${ }^{1}$ They are of the phenylpiperidine family and were synthesized through modifications of the pethidine (meperidine) structure. ${ }^{2}$ Pharmacokinetic properties of fentanyl and its analogues include a highly lipid-soluble structure, 
that allows for effective and rapid diffusion across the blood-brain barrier, contributing to a rapid onset of effects in the central nervous system. ${ }^{1}$ This makes them effective in the management of moderate to severe pain in human and veterinary medicine. However, as with other opioids, possible adverse effects include: respiratory depression, bradycardia, nausea and vomiting, and muscle rigidity of the chest wall or jaw. ${ }^{3-6}$ Timely administration of the antidote naloxone can reverse the effects of respiratory depression after the overdose, however, larger and more frequent administrations may be required due to the increased potency of fentanyl analogues compared to other opioids such as heroin.

As with opioids such as morphine, codeine and oxycodone, fentanyl and its analogues have the potential for misuse. This could either be in the form of abusing licensed and prescribed fentanyls (such as alfentanil, remifentanil and sufentanil) or the use of illicitly manufactured fentanyls (IMF). Both have been implicated in a large number of fatal overdoses worldwide, but particularly concentrated in the United States (US) where the opioid crisis was declared a nationwide public health emergency in $2017 .^{7}$ While the use of the above prescribed fentanyls are restricted to use within hospital and restricted settings, illegal import, manufacturing and distribution remains a key concern. ${ }^{8}$

The US is visibly at the center of the world's opioid crisis with drug overdose deaths exceeding those attributable to firearms, car accidents, homicides, or HIV/AIDS. ${ }^{9}$ This epidemic may be traced back to the mid-1990s when drug companies, such as Purdue Pharma, began promoting their opioid products, prompted by the newly manufactured OxyContin. ${ }^{10}$ OxyContin was widely marketed to effectively alleviate chronic pain with minimal side effects and a low potential for addiction which was later contested, resulting in a US\$ 635 million fine for Purdue Pharma in 2007. ${ }^{11}$ Nonetheless, this led to a decadeslong culture of large-scale commercial advertising of the opioids to the general public and physicians, even lobbying lawmakers and sending representatives to individual doctors to promote their benefits. ${ }^{12}$ However, concerns were raised by some experts about the expertise of primary care prescribers in pain management or addiction issues. ${ }^{13}$ Additionally, in the US there is direct advertising of pharmaceuticals to consumers, encouraging them to ask doctors for specific drugs. ${ }^{14}$ Furthermore, a significant proportion of these doctors are in private practice where patient satisfaction is paramount because there is a great financial benefit in the number of returning patients.

Time trend analysis further confirms deepening opioid crisis in the US. ${ }^{8}$ Opioid-involved overdose deaths in the US have shown steady rise from 18, 515 deaths in 2007 to 47,600 in 2017 , an increase of $157 \%{ }^{15}$ Rates of overdose deaths involving synthetic opioids other than methadone, which includes fentanyl, increased 10\% from 2017 to 2018 with over 31, 000 people dying in $2018 .{ }^{16}$ The Centre for Disease Control and Prevention (CDC) suggests that much of this increase may be due to illegally or illicitly made fentanyls. ${ }^{17}$ Nonetheless, more recently the US has introduced prescription drug monitoring programs for strict monitoring of the prescribing trends. ${ }^{18}$ Prescription drug monitoring programs (PDMPs) are statewide databases in the US that track the controlled drugs dispensing and are accessible to those prescribing and dispensing the drugs as well as to the law enforcement organizations and regulatory bodies. ${ }^{19}$

Many of these opioid overdoses are thought to be unintentional and as a result of contamination of the illicit drug supply on the streets. Illicit contamination with fentanyls is not limited to heroin or counterfeit prescriptionstrength opioid pills - in 2016, three patients died and nine were admitted to hospital after unknowingly taking cocaine that had been laced with fentanyl. ${ }^{20}$ This is particularly concerning because a proportion of cocaine users are opioid-naïve which would likely result in accidental overdose. Furthermore, fentanyl analogues only require marginal doses before resulting in overdose, accentuating their risk.

Outside the US, there is also an increasing trend in the prevalence of opioid including fentanyl use and associated harm in Europe. ${ }^{21,22}$ In 2017, 1300 new synthetic opioids (NSOs) were seized by law enforcement, 72\% of which were fentanyl derivatives. $^{23}$ In 2018, fake Xanax and OxyContin tablets were found to contain fentanyls in Denmark and Sweden, ${ }^{23}$ similar to the previously mentioned incidents that occurred in the US. ${ }^{20}$ The European Monitoring Centre for Drugs and Drug Addiction (EMCDDA) also reported more than 250 deaths linked to fentanyls in Europe in 2016-17. ${ }^{23}$ Lamentably, many fentanyl analogue deaths are also believed to be unreported because, although fentanyl analogues are similar in structure to fentanyl, they are not routinely detected as specialized toxicology testing is required for their precise detection. $^{24}$ 
Novel fentanyl analogues have been steadily emerging on the illicit drug market, posing a migrating global public health risk. The highly potent and lethal nature of fentanyl analogues has implicated them in countless deaths worldwide, taking into account the many that are undetected and unreported. A systematic review highlighting the mortality associated with fentanyl has been published, ${ }^{25}$ however, no review has been conducted regarding fentanyl analogues. Therefore, this review aimed to assess the causes, nature and toxicology of fentanyl-analogue associated fatalities using case reports and case series.

\section{Methods}

\section{Data Search}

A systematic search strategy was employed in this review. Five databases (comprised of Scopus, Embase, Medline, PubMed and Google Scholar) were used to conduct an initial broad search of entries from inception to October 2020 related to deaths associated with fentanyl analogues. The search terms used were "fentanylanalogue", "deaths", "mortality", "fatality", "case report", "case series" and other relevant synonyms.

\section{Study Selection}

Studies were eligible for inclusion if they were case reports or case series that examined fentanyl-analogue related deaths of adults (aged 15 years or above) and were reported in the English Language. Articles focusing solely on fentanyl itself and novel synthetic opioids (NSOs) were excluded from the review.

\section{Data Extraction and Quality Assessment}

A data extraction table was developed which summarized the key information from each article, including demography, route of administration, cause and nature of death, and the fentanyl analogue implicated (Table 1).

\section{Quality Assessment}

All articles were subject to one of the two quality assessment tools developed by the Joanna Briggs Institute (JBI). These tools correlated to either case studies or case series but both were used to critically appraise the results and methodology used within the studies. ${ }^{26}$

\section{Data Synthesis and Analysis}

The independent extraction of data was undertaken by two reviewers (UR, EC). A narrative synthesis was conducted due to the differences and variability within the objectives and results of each study.

\section{Ethics Statement}

This review did not require ethical approval.

\section{Results}

The data search yielded 834 results which were subsequently narrowed down after removing duplications and irrelevant articles. Twenty-nine articles were screened at the full text (including articles found using their bibliographies), resulting in 14 articles - nine case reports and five case series. $^{24,27-39}$ (see Figure 1).

Generally, the case reports were of very good quality clearly describing the demographical information and demonstrating a clear timeline of events. Diagnostic tests for the fentanyl analogues were clearly described by eight out of nine case reports and the majority concluded a clear takeaway message (Table 2).

The quality of the case series was varied with only one out of five articles reporting clinical information of participants and three having a robust consecutive inclusion criterion for their case series. Demographical information for the relevant geographical area could also have been improved in some cases. However, the demographics of participants themselves were well reported, and most statistical analyses were appropriate (Table 3).

\section{Demography}

A total of 1079 fentanyl-analogue related deaths were reported in the included studies. The vast majority of these deaths occurred in the USA ( $\mathrm{n}=1044,96.8 \%)$. This was followed by UK $(n=32,3 \%)$, France $(n=1,<0.1 \%)$, Switzerland $(\mathrm{n}=1,<0.1 \%)$ and Western Australia $(\mathrm{n}=1$, $<0.1 \%$ ). The majority $(71 \%)$ of the total number of deaths were male $(\mathrm{n}=766)$. The highest number of deaths were in the age ranges $25-34$ and $35-44$ years $(30.5 \%$ and $29.6 \%$, respectively). Of the ethnicities that were reported, $87 \%$ of deaths were among white $(\mathrm{n}=884), 10 \%$ black $(\mathrm{n}=101)$, $2 \%$ Hispanic $(\mathrm{n}=20)$ and $1 \%$ "other" $(\mathrm{n}=9)$ individuals.

\section{Routes of Administration}

Approximately half of the incidents $(n=483)$ clearly reported route of administration or could be inferred from the data provided. The most common route of administration was intravenous $(\mathrm{n}=319,66 \%)$, followed by inhalation/snorting $(\mathrm{n}=97,20 \%)$, ingestion $(\mathrm{n}=41,8.5 \%)$, smoking $(n=25,5.2 \%)$ and intralingual $(n=1,0.2 \%)$. 
Table I Characteristics of Included Case Reports and Case Series

\begin{tabular}{|c|c|c|c|c|c|c|c|}
\hline Study ID & Country & $\begin{array}{l}\text { No. of Fentanyl- } \\
\text { Analogue Death } \\
\text { Cases Reported }\end{array}$ & $\begin{array}{l}\text { Study } \\
\text { Design }\end{array}$ & Source of Death & $\begin{array}{l}\text { Inferred Route } \\
\text { of } \\
\text { Administration }\end{array}$ & Cause of Death & Nature of Death \\
\hline $\begin{array}{l}\text { Brockbals } \\
\text { et al } 2019^{27}\end{array}$ & Switzerland & $\begin{array}{l}n=1 \\
\text { - Male } \\
\text { - Age: } 39\end{array}$ & $\begin{array}{l}\text { Case } \\
\text { report }\end{array}$ & Cyclopropylfentanyl & Inhalation & $\begin{array}{l}\text { Combined intoxication } \\
\text { with ethanol and } \\
\text { cyclopropylfentanyl }\end{array}$ & Unspecified \\
\hline $\begin{array}{l}\text { Butler et al } \\
2017^{28}\end{array}$ & USA & $\begin{array}{l}n=3 \\
\text { - Male: } 3 \\
\text { - Age range: } 23-43\end{array}$ & $\begin{array}{l}\text { Case } \\
\text { report }\end{array}$ & $\begin{array}{l}\text { Acrylfentanyl } \\
\text { Furanylfentanyl }\end{array}$ & $\begin{array}{l}\text { Intravenous } \\
(n=3)\end{array}$ & $\begin{array}{l}\text { Acrylfentanyl toxicity }(n=1) \\
\text { Toxic effects of acryfentanyl } \\
\text { and hydrocodone }(n=1) \\
\text { Acryfentanyl and } \\
\text { furanylfentanyl toxicity } \\
(n=1)\end{array}$ & Accidental $(n=3)$ \\
\hline $\begin{array}{l}\text { Castellino } \\
\text { et al } 2020^{29}\end{array}$ & USA & $\begin{array}{l}n=2 \\
\text { - Male: } 2 \\
\text { - Age range: } 24-25 \\
\text { - Caucasian }\end{array}$ & $\begin{array}{l}\text { Case } \\
\text { report }\end{array}$ & Cyclopropylfentanyl & Not specified & $\begin{array}{l}\text { Cyclopropylfentanyl } \\
\text { overdose }(n=I) \\
\text { Mixed drug toxicity }(n=I)\end{array}$ & Accidental $(n=2)$ \\
\hline $\begin{array}{l}\text { Corsi et al } \\
2019^{30}\end{array}$ & USA & $\begin{array}{l}\mathrm{n}=17 \\
\text { - Male: } 15 \text { Female: } 2 \\
\text { - Age range: } 21-5 \mid \\
\text { - Caucasian: } 15 \\
\text { - African-American: } 2\end{array}$ & $\begin{array}{l}\text { Case } \\
\text { series }\end{array}$ & Carfentanil & $\begin{array}{l}\text { Intravenous } \\
(n=5) \\
\text { Undetermined } \\
(n=12)\end{array}$ & $\begin{array}{l}\text { Drug abuse }(n=10) \\
\text { Drug intoxication }(n=6) \\
\text { Drug overdose }(n=1)\end{array}$ & $\begin{array}{l}\text { Suicide by } \\
\text { overdose }(n=1) \\
\text { Undetermined } \\
(n=17)\end{array}$ \\
\hline $\begin{array}{l}\text { Daniulaityte } \\
\text { et al } 2017^{31}\end{array}$ & USA & $\begin{array}{l}n=281 \\
\text { - Male: } 181 \text { Female: } 100 \\
\text { - Age range: } \\
\text { - White, non-Hispanic: } \\
257 \\
\text { - Black or other: } 24\end{array}$ & $\begin{array}{l}\text { Case } \\
\text { series }\end{array}$ & $\begin{array}{l}\text { Fentanyl } \\
\text { Norfentanyl } \\
\text { Acrylfentanyl } \\
\text { Furanylfentanyl } \\
\text { Carfentanil }\end{array}$ & Unspecified & Drug overdose $(n=281)$ & $\begin{array}{l}\text { Accidental } \\
(n=28 I)\end{array}$ \\
\hline $\begin{array}{l}\text { Elliott et al } \\
2018^{32}\end{array}$ & UK & $\begin{array}{l}\mathrm{n}=7 \\
\text { - Male: } 5 \text { Female: } 2 \\
\text { - Age range: } 29-44\end{array}$ & $\begin{array}{l}\text { Case } \\
\text { series }\end{array}$ & Carfentanil & $\begin{array}{l}\text { Intravenous } \\
(n=1) \\
\text { Not specified } \\
(n=6)\end{array}$ & Mixed drug toxicity $(n=7)$ & $\begin{array}{l}\text { Undetermined but } \\
\text { hinted to be } \\
\text { accidental }\end{array}$ \\
\hline $\begin{array}{l}\text { Fagiola et al } \\
2018^{33}\end{array}$ & USA & $\begin{array}{l}n=5 \\
\text { - Male: } 4 \text { Female: } 1 \\
\text { - Age ranges: } 19-49 \\
\text { - White: } 5\end{array}$ & $\begin{array}{l}\text { Case } \\
\text { report }\end{array}$ & Cyclopropylfentanyl & $\begin{array}{l}\text { Intravenous } \\
(n=1) \\
\text { Inhalation }(n=1) \\
\text { Unspecified } \\
(n=3)\end{array}$ & Mixed drug toxicity $(n=5)$ & Accidental $(n=5)$ \\
\hline $\begin{array}{l}\text { Gaulier et al } \\
2019^{34}\end{array}$ & France & $\begin{array}{l}\mathrm{n}=\mathrm{I} \\
\text { - Male } \\
\text { - Age: } 4 \mathrm{l}\end{array}$ & $\begin{array}{l}\text { Case } \\
\text { report }\end{array}$ & Carfentanil & Intralingual & Mixed drug toxicity & Accidental \\
\hline $\begin{array}{l}\text { Hikin et al } \\
2018^{35}\end{array}$ & UK & $\begin{array}{l}\mathrm{n}=25 \\
\text { - Male: } 22 \text { Female: } 3 \\
\text { - Age range: } 2 \mathrm{I}-54\end{array}$ & $\begin{array}{l}\text { Case } \\
\text { series }\end{array}$ & $\begin{array}{l}\text { Carfentanil } \\
\text { Butyryl fentanyl } \\
\text { 4F-butyryl fentanyl } \\
\text { Furanyl fentanyl }\end{array}$ & Unspecified & Mixed drug toxicity $(n=25)$ & Unspecified \\
\hline $\begin{array}{l}\text { Krotulski } \\
\text { et al } 2017^{36}\end{array}$ & USA & $\begin{array}{l}n=1 \\
\text { - Male } \\
\text { - Age: } 31 \\
\text { - White }\end{array}$ & $\begin{array}{l}\text { Case } \\
\text { report }\end{array}$ & $\begin{array}{l}\text { Tetrahydrofuranyl- } \\
\text { fentanyl }\end{array}$ & Intravenous & Mixed drug toxicity & Accidental \\
\hline $\begin{array}{l}\text { Moss et al } \\
2019^{37}\end{array}$ & $\begin{array}{l}\text { Western } \\
\text { Australia }\end{array}$ & $\begin{array}{l}n=1 \\
\text { - Male } \\
\text { - Age: } 24\end{array}$ & $\begin{array}{l}\text { Case } \\
\text { report }\end{array}$ & Acetylfentanyl & Intravenous & Acetylfentanyl toxicity & Accidental \\
\hline
\end{tabular}

(Continued) 
Table I (Continued).

\begin{tabular}{|c|c|c|c|c|c|c|c|}
\hline Study ID & Country & $\begin{array}{l}\text { No. of Fentanyl- } \\
\text { Analogue Death } \\
\text { Cases Reported }\end{array}$ & $\begin{array}{l}\text { Study } \\
\text { Design }\end{array}$ & Source of Death & $\begin{array}{l}\text { Inferred Route } \\
\text { of } \\
\text { Administration }\end{array}$ & Cause of Death & Nature of Death \\
\hline $\begin{array}{l}\text { O'Donnell } \\
\text { et al } 2017^{24}\end{array}$ & USA & $\begin{array}{l}\mathrm{n}=720 \\
\text { - Male: } 520 \text { Female: } 200 \\
\text { - Age range: }<15 \text { - >65 } \\
\text { - White, non-Hispanic: } \\
602 \\
\text { - Black, non-Hispanic: } 75 \\
\text { - Other, non-Hispanic: } 9 \\
\text { - Hispanic: } 20\end{array}$ & $\begin{array}{l}\text { Case } \\
\text { series }\end{array}$ & $\begin{array}{l}\text { Carfentanil } \\
\text { Furanylfentanyl } \\
\text { Acetylfentanyl }\end{array}$ & $\begin{array}{l}\text { Intravenous } \\
(n=303) \\
\text { Inhalation }(n=95) \\
\text { Ingestion }(n=41) \\
\text { Smoking }(n=25) \\
\text { Unspecified } \\
(n=279)\end{array}$ & $\begin{array}{l}\text { - Fentanyl analogue toxicity } \\
\text { - Mixed drug/polydrug } \\
\text { toxicity } \\
\text { - Specific numbers unclear }\end{array}$ & Unspecified \\
\hline $\begin{array}{l}\text { Shanks et al } \\
2017^{38}\end{array}$ & USA & $\begin{array}{l}\mathrm{n}=13 \\
\text { - Male: } 8 \text { Female: } 5 \\
\text { - Age range: } 25-62\end{array}$ & $\begin{array}{l}\text { Case } \\
\text { report }\end{array}$ & Carfentanil & $\begin{array}{l}\text { Intravenous } \\
(n=3) \\
\text { Unspecified } \\
(n=10)\end{array}$ & $\begin{array}{l}\text { Carfentanil drug toxicity } \\
(n=7) \\
\text { Mixed carfentanil and } \\
\text { fentanyl toxicity }(n=2) \\
\text { Mixed drug intoxication } \\
(n=4)\end{array}$ & Accidental $(n=13)$ \\
\hline $\begin{array}{l}\text { Swanson } \\
\text { et al } 2017^{39}\end{array}$ & USA & $\begin{array}{l}\mathrm{n}=2 \\
\text { - Male: } 2 \\
\text { - Age range: } 25-34 \\
\text { - White: } 2\end{array}$ & $\begin{array}{l}\text { Case } \\
\text { report }\end{array}$ & $\begin{array}{l}\text { Carfentanil } \\
\text { Furanylfentanyl }\end{array}$ & $\begin{array}{l}\text { Intravenous } \\
(n=1) \\
\text { Unspecified } \\
(n=1)\end{array}$ & $\begin{array}{l}\text { Mixed drug toxicity }(n=1) \\
\text { Carfentanil overdose }(n=1)\end{array}$ & Accidental $(n=2)$ \\
\hline
\end{tabular}

\section{Nature of Deaths}

The nature of death was only reported in 310 deaths out of the included 1079. Of these 310, approximately all were accidental (99.7\%) with one classed as suicide by overdose.

\section{Cause of Deaths}

The cause of death was only clearly reported in 342 cases. The most predominant cause of death was toxicity due to the fentanyl analogue alone $(\mathrm{n}=292,85.4 \%)$, followed by mixed drug toxicity $(\mathrm{n}=47,13.7 \%)$, combined intoxication with a fentanyl analogue and fentanyl $(\mathrm{n}=2,0.6 \%)$ and combined intoxication with two fentanyl analogues $(\mathrm{n}=1$, $0.3 \%$ ). Causes of death involving ethanol were classed as mixed drug toxicity. One study reported five decedents having pre-existing medical conditions that may have contributed to their cause of death. ${ }^{30}$ However, the official causes of death that were reported by this case series were vaguely determined as "drug abuse" $(\mathrm{n}=10)$, "drug intoxication" ( $(n=6)$ and "drug overdose" $(n=1)$. Therefore, these causes were excluded from this analysis.

The most common concomitant drugs used where the deaths were reported due to mixed drug toxicity were opioids, with the most prevalent being heroin, morphine, and oxycodone (Table 4). Other classes of drugs that were used concomitantly included CNS stimulants (such as cocaine and methamphetamine), benzodiazepines, anti-depressants, and anti-epileptics. Corsi et al examined 17 fatal overdoses involving carfentanil and found that there was not a single case with only carfentanil in the bloodstream. ${ }^{30}$

\section{Toxicology}

Post-mortem fentanyl analogue concentrations were reported in nine out of 14 studies. The range of concentrations was very wide, $0.0104-400 \mathrm{ng} / \mathrm{mL}$ (mean $31.6 \mathrm{ng} /$ $\mathrm{mL}$; median $0.340 \mathrm{ng} / \mathrm{mL}$ ). When excluding two significant outliers this range becomes 0.0104 to $82 \mathrm{ng} / \mathrm{mL}$ (mean $6.55 \mathrm{ng} / \mathrm{mL}$; median $0.320 \mathrm{ng} / \mathrm{mL}$ ). Moss et al acknowledged the relatively high concentration of 400 $\mathrm{ng} / \mathrm{mL}$ acetylfentanyl in the deceased as being unusual. ${ }^{37}$

Variation in fentanyl analogue blood toxicology was expected due to the nature and structure of individual fentanyl analogues, the cause of death, the route of administration, the site of blood withdrawal and the degree of opioid tolerance of the deceased.

There were no significant trends in the post-mortem blood toxicology findings when considering the different fentanyl analogues (Table 5), although this could be due to a lack of sufficient data. Although fentanyl analogues share a similar basic chemical structure, subtle differences can impact their chemical and pharmacological properties. For example, higher $\log \mathrm{P}$ values, which direct the lipophilicity of the drug, will 


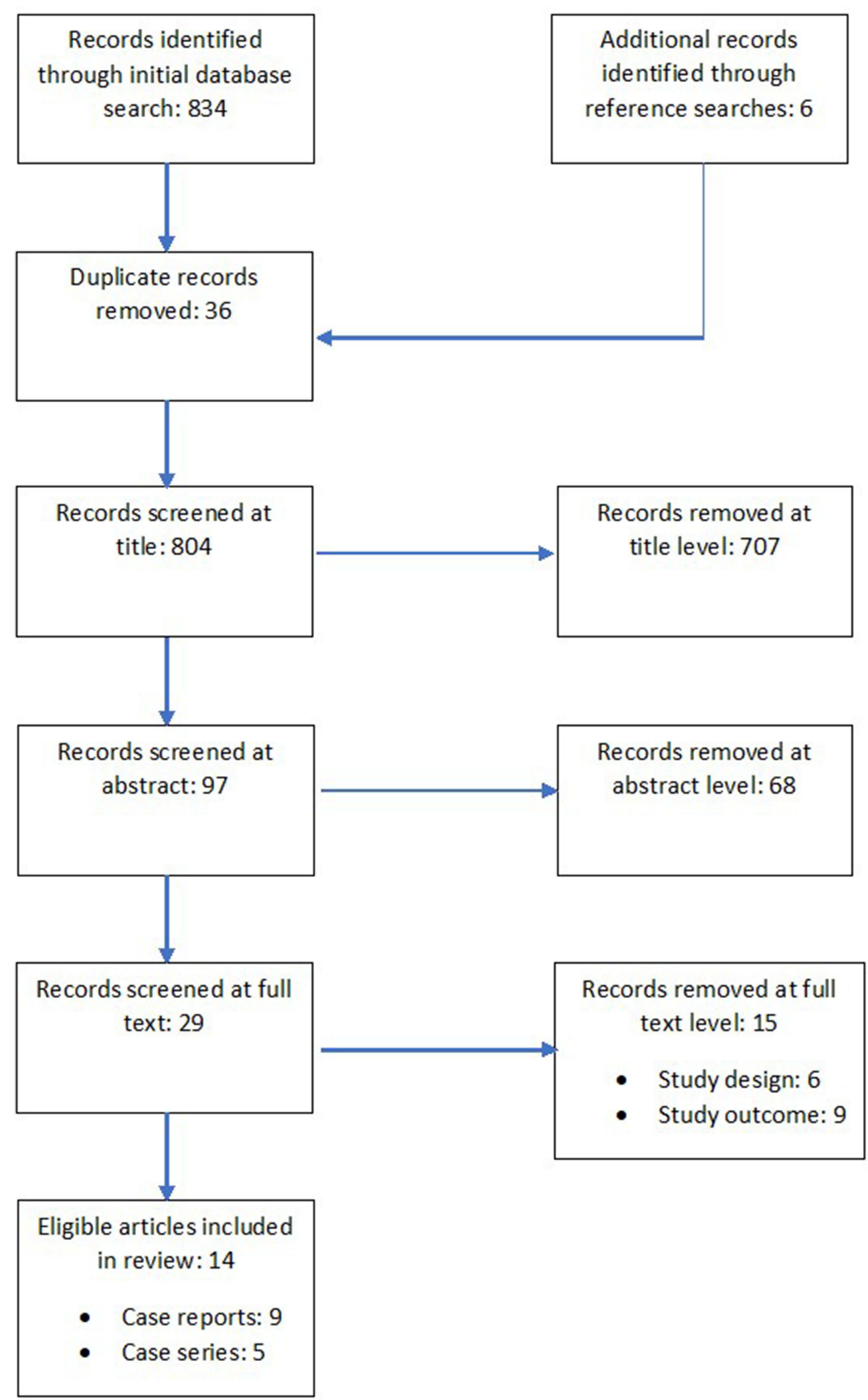

Figure I PRSIMA flow diagram.

Notes: PRISMA figure adapted from Liberati A, Altman D, Tetzlaff J, et al. The PRISMA statement for reporting systematic reviews and meta-analyses of studies that evaluate health care interventions: explanation and elaboration. Journal of Clinical Epidemiology. 2009;62(10)el-e34. Creative Commons.

allow for rapid diffusion across membranes such as the bloodbrain barrier, as previously stated. Drugs with a high $\log \mathrm{P}$ value, a high volume of distribution $(\mathrm{Vd}>3 \mathrm{~L} / \mathrm{kg})$ and that are a base are likely to undergo post-mortem redistribution (PMR). ${ }^{40}$ PMR is the change in drug concentration from a high concentration to a low concentration after death. Fentanyl has been reported to undergo extensive PMR, ${ }^{40}$ however, pharmacological data on fentanyl analogues is lacking and, therefore, such inferences cannot yet be made for them. However, if they do undergo significant PMR, the blood toxicology results retrieved from the included articles should be reviewed because the site and timing of blood withdrawal may have influenced the blood concentrations that were recorded. 
Table 2 Quality Assessment of Included Case Reports

\begin{tabular}{|c|c|c|c|c|c|c|c|c|c|}
\hline & $\begin{array}{c}\text { Brockbals } \\
\text { et al } \\
2019^{27}\end{array}$ & $\begin{array}{l}\text { Butler } \\
\text { et al } \\
2017^{28}\end{array}$ & $\begin{array}{l}\text { Castellino } \\
\text { et al } \\
2020^{29}\end{array}$ & $\begin{array}{c}\text { Fagiola } \\
\text { et al } \\
2018^{33}\end{array}$ & $\begin{array}{l}\text { Gaulier } \\
\text { et al } \\
2019^{34}\end{array}$ & $\begin{array}{c}\text { Krotulski } \\
\text { et al } \\
2017^{36}\end{array}$ & $\begin{array}{l}\text { Moss } \\
\text { et al } \\
2019^{37}\end{array}$ & $\begin{array}{c}\text { Shanks } \\
\text { et al } \\
2017^{37}\end{array}$ & $\begin{array}{c}\text { Swanson } \\
\text { et al } \\
2017^{39}\end{array}$ \\
\hline $\begin{array}{l}\text { Were patient's demographic } \\
\text { characteristics clearly } \\
\text { described? }\end{array}$ & $\checkmark$ & $\checkmark$ & $\checkmark$ & $\checkmark$ & $\checkmark$ & $\checkmark$ & $\checkmark$ & $\checkmark$ & $\checkmark$ \\
\hline $\begin{array}{l}\text { Was the patient's history } \\
\text { clearly described and } \\
\text { presented as a timeline? }\end{array}$ & $\checkmark$ & $\checkmark$ & $\checkmark$ & $\checkmark$ & $\checkmark$ & $\checkmark$ & $\checkmark$ & $\checkmark$ & $\checkmark$ \\
\hline $\begin{array}{l}\text { Was the current clinical } \\
\text { condition of the patient on } \\
\text { presentation clearly } \\
\text { described? }\end{array}$ & $\checkmark$ & $\checkmark$ & $\checkmark$ & $\checkmark$ & $\checkmark$ & $\checkmark$ & $\checkmark$ & $\checkmark$ & $\checkmark$ \\
\hline $\begin{array}{l}\text { Were diagnostic tests or } \\
\text { assessment methods and } \\
\text { the results clearly } \\
\text { described? }\end{array}$ & $\checkmark$ & $\checkmark$ & $\checkmark$ & $\checkmark$ & $\checkmark$ & $\checkmark$ & $\checkmark$ & $\checkmark$ & $\checkmark$ \\
\hline $\begin{array}{l}\text { Was the intervention(s) or } \\
\text { treatment procedure(s) } \\
\text { clearly described? }\end{array}$ & $N / A$ & $N / A$ & $N / A$ & $N / A$ & $\mathrm{~N} / \mathrm{A}$ & $N / A$ & $N / A$ & $N / A$ & N/A \\
\hline $\begin{array}{l}\text { Was the post-intervention } \\
\text { clinical condition clearly } \\
\text { described? }\end{array}$ & N/A & $N / A$ & $N / A$ & $\mathrm{~N} / \mathrm{A}$ & N/A & N/A & $N / A$ & $N / A$ & N/A \\
\hline $\begin{array}{l}\text { Were adverse events } \\
\text { (harms) or unanticipated } \\
\text { events identified and } \\
\text { described? }\end{array}$ & $\checkmark$ & $\checkmark$ & $\checkmark$ & $\checkmark$ & $\checkmark$ & $\checkmark$ & $\checkmark$ & $\checkmark$ & $\checkmark$ \\
\hline $\begin{array}{l}\text { Does the case report } \\
\text { provide takeaway lessons? }\end{array}$ & $\checkmark$ & $\checkmark$ & $\checkmark$ & $\checkmark$ & $\checkmark$ & - & $\checkmark$ & - & $\checkmark$ \\
\hline Yes & \multicolumn{3}{|l|}{ No } & \multicolumn{3}{|l|}{ Unclear } & \multicolumn{3}{|c|}{ Not Applicable } \\
\hline$\checkmark$ & $x$ & & & - & & & $N / A$ & & \\
\hline
\end{tabular}

Note: Adapted from Joanna Briggs Institute (JBI).

\section{Discussion}

This is the first study of its kind that has reviewed the case reports and case series related to deaths attributed to fentanyl analogues. Nine case reports and five case series involving fatalities associated with various fentanyl analogues were reviewed. The majority of decedents were white males between the ages of 25 and 34 years and living in the United States. The main causes of death were fentanyl analogue overdoses and deaths due to mixed drug toxicity. The most concomitant drugs used in these fatalities were opioids (such as heroin, morphine, and oxycodone) and a large number also used benzodiazepines and CNS stimulants such as cocaine and methamphetamine. It remains unclear if post-mortem blood fentanyl analogue levels had any correlation with the route of administration or cause of death.

Concurrent drug use by decedents was very common in the included studies. All but two fatalities in the case reports showed evidence of the presence of other drugs in their system at their time of death. Increased tolerance to opioids can and does lead to diversion in the presence of other opioids, seeking out more potent varieties. 
Table 3 Quality Assessment of Included Case Series

\begin{tabular}{|c|c|c|c|c|c|}
\hline & $\begin{array}{l}\text { Corsi et al } \\
2019^{2330}\end{array}$ & $\begin{array}{c}\text { Daniulaityte } \\
\text { et al } 2017^{24} \\
31\end{array}$ & $\begin{array}{c}\text { Elliott } \\
\text { et al } \\
2018^{25} \\
32\end{array}$ & $\begin{array}{l}\text { Hikin et al } \\
2018^{2835}\end{array}$ & $\begin{array}{l}\text { O'Donnell et al } \\
2017^{1824}\end{array}$ \\
\hline Were there clear criteria for inclusion in the case series? & $\checkmark$ & $\checkmark$ & - & $\checkmark$ & $\checkmark$ \\
\hline $\begin{array}{l}\text { Was the condition measured in a standard, reliable way for all } \\
\text { participants included in the case series? }\end{array}$ & $\checkmark$ & $\checkmark$ & $\checkmark$ & $\checkmark$ & $\checkmark$ \\
\hline $\begin{array}{l}\text { Were valid methods used for identification of the condition for } \\
\text { all participants included in the case series? }\end{array}$ & $\checkmark$ & $\checkmark$ & $\checkmark$ & $\checkmark$ & $\checkmark$ \\
\hline Did the case series have consecutive inclusion of participants? & $\checkmark$ & - & $\checkmark$ & $\checkmark$ & $\checkmark$ \\
\hline Did the case series have complete inclusion of participants? & $\checkmark$ & $\checkmark$ & - & $\checkmark$ & $\checkmark$ \\
\hline $\begin{array}{l}\text { Was there clear reporting of the demographics of the } \\
\text { participants in the study? }\end{array}$ & $\checkmark$ & $\checkmark$ & $\checkmark$ & - & $\checkmark$ \\
\hline $\begin{array}{l}\text { Was there clear reporting of clinical information of the } \\
\text { participants? }\end{array}$ & $\checkmark$ & $\checkmark$ & $\checkmark$ & $\checkmark$ & $\checkmark$ \\
\hline $\begin{array}{l}\text { Were the outcomes or follow up results of cases clearly } \\
\text { reported? }\end{array}$ & $\mathrm{N} / \mathrm{A}$ & $\mathrm{N} / \mathrm{A}$ & $\mathrm{N} / \mathrm{A}$ & N/A & N/A \\
\hline $\begin{array}{l}\text { Was there clear reporting of the presenting site(s)/clinic(s) } \\
\text { demographic information? }\end{array}$ & - & $\checkmark$ & $\checkmark$ & $\checkmark$ & $\checkmark$ \\
\hline Was statistical analysis appropriate? & - & $\checkmark$ & - & $\checkmark$ & $\checkmark$ \\
\hline Yes & \multicolumn{2}{|l|}{ No } & \multicolumn{2}{|l|}{ Unclear } & Not Applicable \\
\hline$\checkmark$ & \multicolumn{2}{|l|}{$x$} & \multicolumn{2}{|l|}{-} & $\mathrm{N} / \mathrm{A}$ \\
\hline
\end{tabular}

Note: Adapted from Joanna Briggs Institute (JBI).

Simultaneous use will produce greater intoxicating effects but will additionally increase the chances of CNS depression and subsequent sedation and possibly even coma or death. These consequences are not only restricted to the concomitant use of opioids with fentanyl analogues but can also be caused by the synergistic effects of benzodiazepines with the use of fentanyls, or antiepileptics with the use of fentanyls by a similar mode of action. The Medicines and Healthcare products Regulatory Agency (MHRA) explicitly states caution in the use of these drugs with opioids due to the potential risk of fatal respiratory depression. ${ }^{41,42}$ Prescribers should always be cautious of signs of drug abuse, dependence, and drug-seeking behavior in their patients before prescribing these drugs. The risk of potentially fatal interactions should be expressly communicated to patients and they should also be aware of signs of dependence. It is important to educate the public on the use of commonly prescribed and readily available drugs because abuse frequently originates with prescribed opioids before tolerance leads to the seeking out of more potent drugs such as fentanyls.

No firm conclusions can be drawn regarding the influence of the route of administration on post-mortem fentanyl analogue concentrations due to a lack of sufficient data for comparisons. However, it can be safely assumed that fentanyl analogues will follow the same bioavailability principles as other drugs and, therefore, intravenous administration should result in the highest drug concentrations in the blood due to being $100 \%$ bioavailable. Drugs administered orally or inhaled will undergo some first-pass metabolism and will demonstrate less than $100 \%$ bioavailability, resulting in lower blood concentrations. The extent to which each fentanyl analogue undergoes PMR will also impact on the blood concentrations recorded.

The degree of opioid tolerance at the time of death may be linked to the decedents' blood toxicology recorded. There were only two fentanyl analogue fatalities documented in the included studies which did not 
Table 4 Drugs Suspected in Fentanyl Analogues Associated Deaths Classed as a Mixed Drug Toxicity

\begin{tabular}{|c|c|c|c|}
\hline Drug Class & $\begin{array}{l}\text { Drugs Reported in Blood and/or } \\
\text { Urine of the Deceased }\end{array}$ & $\begin{array}{l}\text { Total Number } \\
\text { Reported in } \\
\text { Toxicology }\end{array}$ & $\begin{array}{c}\text { Proportion of Drug Class Which Contributed to } \\
\text { Total Fentanyl Analogue Deaths (\%) }\end{array}$ \\
\hline $\begin{array}{l}\text { Anti-depressant } \\
\text { /Anti-psychotic }\end{array}$ & $\begin{array}{l}\text { Mirtazapine }(n=6) \\
\text { Sertraline }(n=6) \\
\text { Amitriptyline }(n=2) \\
\text { Olanzapine }(n=2) \\
\text { Trazodone }(n=2) \\
\text { Aripiprazole }(n=1) \\
\text { Clozapine }(n=1) \\
\text { Duloxetine }(n=1) \\
\text { Nortriptyline }(n=1) \\
\text { Paroxetine }(n=1) \\
\text { Quetiapine }(n=1)\end{array}$ & 24 & 2.22 \\
\hline Antiepileptic & $\begin{array}{l}\text { Gabapentin }(n=15) \\
\text { Pregabalin }(n=5) \\
\text { Topiramate }(n=2) \\
\text { Phenytoin }(n=1)\end{array}$ & 23 & 2.13 \\
\hline Antihypertensive & $\begin{array}{l}\text { Clonidine }(n=1) \\
\text { Lisinopril }(n=I) \\
\text { Loperamide }(n=I)\end{array}$ & 3 & 0.28 \\
\hline \multirow[t]{2}{*}{ Benzodiazepine } & $\begin{array}{l}\text { Alprazolam } \\
\text { Clonazepam } \\
\text { Diazepam } \\
\text { Nitrazepam } \\
\text { Oxazepam } \\
\text { Temazepam }\end{array}$ & 107 & 9.92 \\
\hline & Cannabinoids & 113 & 10.47 \\
\hline CNS stimulants & $\begin{array}{l}\text { Cocaine }(n=305) \\
\text { Methamphetamine }(n=|0|) \\
\text { Amphetamine }(n=4)\end{array}$ & 410 & 38.00 \\
\hline $\begin{array}{l}\text { Hypnotic/ } \\
\text { tranquilizer }\end{array}$ & $\begin{array}{l}\text { Ketamine }(n=2) \\
\text { Zolpidem }(n=2) \\
\text { Zopiclone }(n=2) \\
\text { Zolmitriptan }(n=1)\end{array}$ & 7 & 0.65 \\
\hline \multirow[t]{2}{*}{ Opioid } & $\begin{array}{l}\text { Heroin }(n=292) \\
\text { Morphine }(n=49) \\
\text { Oxycodone }(n=32) \\
\text { Methadone }(n=21) \\
\text { Codeine }(n=18) \\
\text { Hydrocodone }(n=17) \\
\text { Tramadol }(n=12) \\
\text { Hydromorphone }(n=6) \\
\text { Buprenorphine }(n=4) \\
\text { Oxymorphone }(n=4) \\
\text { Dihydrocodeine }(n=2) \\
\text { U-47700 }(n=2)\end{array}$ & 459 & 42.53 \\
\hline & Phencyclidine & I & 0.09 \\
\hline
\end{tabular}

(Continued) 
Table 4 (Continued).

\begin{tabular}{|l|l|c|c|}
\hline Drug Class & $\begin{array}{l}\text { Drugs Reported in Blood and/or } \\
\text { Urine of the Deceased }\end{array}$ & $\begin{array}{c}\text { Total Number } \\
\text { Reported in } \\
\text { Toxicology }\end{array}$ & $\begin{array}{c}\text { Proportion of Drug Class Which Contributed to } \\
\text { Total Fentanyl Analogue Deaths (\%) }\end{array}$ \\
\hline $\begin{array}{l}\text { Sedating } \\
\text { antihistamine }\end{array}$ & $\begin{array}{l}\text { Promethazine }(n=2) \\
\text { Chlorpheniramine }(n=1) \\
\text { Diphenhydramine }(n=1)\end{array}$ & 4 & 0.37 \\
\hline
\end{tabular}

Note: Precise Figures For Benzodiazepine Drugs Not Recorded As Some Case Series Recorded Benzodiazepines As Their Own Standalone Category.

have any other concomitant drugs in their blood. Both had died of a carfentanil overdose and their blood toxicology showed their postmortem carfentanil concentrations were lower than the average carfentanil concentration of $0.503 \mathrm{ng} / \mathrm{mL} \quad(0.221 \quad$ and $0.105 \mathrm{ng} / \mathrm{mL}$ ). The lack of concomitant drugs illustrates that carfentanil was solely responsible for their deaths and they may be slightly more opioid naive compared to other decedents whose chronic multidrug use could have increased their levels of opioid tolerance, resulting in the administration of higher fentanyl analogue doses and subsequently higher post-mortem concentrations. It should be emphasized that there is no minimum concentration threshold for a fentanyl analogue to result in death.

In some case reports, the circumstances that the bodies of the decedents were found in suggested that the death was abrupt and unexpected. One such case was reported by Swanson et al where the deceased was found slumped over in the driver's seat of a van that was parked in a car wash, and the car was still running. ${ }^{39}$ Another instance, described by Fagiola et al, occurred where the decedent was found with a needle still in his arm at a car patrol station $^{33}$ and a similar example was reported by Gaulier et al where the individual who was staying at his grandparents' house was found with a $2.5 \mathrm{~mL}$ syringe still planted under his tongue. ${ }^{34}$ The reason for such sudden deaths with the intravenous route of administration stems from rapid absorption of the fentanyl analogue across the blood-brain barrier due to its high lipophilicity and $100 \%$ bioavailability which exposes the individual to its full effects immediately.

As aforementioned, fentanyl analogues are not routinely screened for in post-mortem toxicology which makes it difficult to notice the trends in drug-related deaths. Even if they are screened for, they are difficult to detect without very sensitive methods of analysis due to their low concentrations in the body resulting from their high potency.
This suggests that there may be many fentanyl analogue associated deaths that are unreported worldwide, leading to many factions underestimating the devastating effects caused by these drugs. Marchei et al reported that liquid chromatography combined with tandem mass spectrometry (LC-MS/MS) and gas chromatography with mass spectrometry (GC-MS) are the most common techniques used to detect fentanyl analogues, ${ }^{43}$ a detail that is supported by most of the studies included in this review. Both techniques have extremely high specificity and sensitivity. However, they are limited by the continued emergence of new fentanyl analogues of which there are no available reference standards to be used during comparative analyses. ${ }^{40}$ In fact, more than 30 fentanyl analogues have been detected and reported to EMCDDA since 2012, ${ }^{44}$ therefore, experts are unlikely to obtain these reference standards in adequate time before fatalities commence. Alternatively, one potential prospect is the use of liquid chromatography quadruple time-of-flight mass spectroscopy (LC-QTOF-MS) which does not require reference standards when identifying unknown standards and, therefore, this will be beneficial in the fight against new oncoming fentanyl analogues. ${ }^{40}$ However, this technology is limited to few forensic laboratories and is not readily available. Nonetheless, testing for fentanyl analogues should become routine whether using GC/MS, LC-MS /MS or LC-QTOF-MS and the case reports should clearly state if the testing is not employed. This will help account for fentanyl analogue-related deaths that did not involve any testing, as recommended in a report by the ACMD. ${ }^{14}$

\section{Strengths and Limitations}

This review is the first of its kind in compiling and analyzing peer-reviewed literature on the mortalities associated with fentanyl analogues. The findings related to demography, causes of death, and concurrent drug use are of significant importance. However, this report does have some limitations. Fentanyl analogues are not always 
Table 5 Reported Toxicology from Included Case Reports

\begin{tabular}{|c|c|c|c|c|c|}
\hline Fentanyl Analogue & $\begin{array}{l}\text { Patient } \\
\text { Demographic } \\
\text { (Gender, Age) }\end{array}$ & $\begin{array}{l}\text { Route of } \\
\text { Administration }\end{array}$ & Cause of Death & $\begin{array}{l}\text { Fentanyl Analogue } \\
\text { Concentration }(\mathrm{ng} / \mathrm{mL}) \\
\text { from Specified Blood } \\
\text { Source }\end{array}$ & $\begin{array}{l}\text { Evidence of } \\
\text { Concomitant } \\
\text { Drugs }\end{array}$ \\
\hline Acetylfentanyl & Male, 24 [30] & Intravenous & $\begin{array}{l}\text { Fentanyl analogue } \\
\text { overdose }\end{array}$ & Source not specified: 400 & Yes \\
\hline \multirow[t]{3}{*}{ Acrylfentanyl } & Male, $23[2 I]$ & Intravenous & $\begin{array}{l}\text { Fentanyl analogue } \\
\text { overdose }\end{array}$ & Peripheral: 0.3 & Yes \\
\hline & Male, $43[21]$ & Intravenous & Mixed drug intoxication & Peripheral: 0.95 & Yes \\
\hline & Male, $26[21]$ & Intravenous & Mixed drug intoxication & Peripheral: 0.32 & Yes \\
\hline \multirow[t]{16}{*}{ Carfentanil } & Male, 4I [27] & Intralingual & $\begin{array}{l}\text { Fentanyl analogue } \\
\text { overdose }\end{array}$ & $\begin{array}{l}\text { Source not specified: } \\
4.2\end{array}$ & Yes \\
\hline & Female, 26 [3I] & Unspecified & $\begin{array}{l}\text { Fentanyl analogue } \\
\text { overdose }\end{array}$ & Iliac: 0.234 & Yes \\
\hline & Male, 38 [3I] & Unspecified & $\begin{array}{l}\text { Fentanyl analogue } \\
\text { overdose }\end{array}$ & Femoral: 0.221 & No \\
\hline & Female, 36 [3I] & Unspecified & $\begin{array}{l}\text { Fentanyl analogue } \\
\text { overdose }\end{array}$ & Femoral: 0.107 & Yes \\
\hline & Female, 33 [31] & Unspecified & Mixed drug intoxication & Iliac: 0.145 & Yes \\
\hline & Male, 25 [3I] & Intravenous & Mixed drug intoxication & Cardiac: $0.24 \mathrm{I}$ & Yes \\
\hline & Female, 44 [3I] & Unspecified & $\begin{array}{l}\text { Fentanyl analogue } \\
\text { overdose }\end{array}$ & Femoral: 0.105 & No \\
\hline & Male, $28[3 \mathrm{I}]$ & Unspecified & $\begin{array}{l}\text { Fentanyl analogue } \\
\text { overdose }\end{array}$ & Iliac: 0.0233 & Yes \\
\hline & Male, $38[31]$ & Intravenous & $\begin{array}{l}\text { Fentanyl analogue } \\
\text { overdose }\end{array}$ & Subclavian: $0.030 \mathrm{I}$ & Yes \\
\hline & Male, 44 [3I] & Unspecified & Multiple drug toxicity & Femoral: 0.114 & Yes \\
\hline & Male, $50[31]$ & Unspecified & $\begin{array}{l}\text { Fentanyl analogue } \\
\text { overdose }\end{array}$ & Subclavian: 0.617 & Yes \\
\hline & Male, $27[3 \mid]$ & Unspecified & $\begin{array}{l}\text { Fentanyl analogue } \\
\text { overdose }\end{array}$ & Femoral: 0.529 & Yes \\
\hline & Female, $62[31]$ & Unspecified & Multiple drug toxicity & Femoral: 0.0457 & Yes \\
\hline & Male, $39[31]$ & Intravenous & Mixed drug intoxication & Femoral: 0.0104 & Yes \\
\hline & Male, 34 [32] & Intravenous & Mixed drug intoxication & Cardiac: 1.3 & Yes \\
\hline & Male, 25 [32] & Unspecified & $\begin{array}{l}\text { Fentanyl analogue } \\
\text { overdose }\end{array}$ & Cardiac: 0.12 & Yes \\
\hline
\end{tabular}

(Continued) 
Table 5 (Continued).

\begin{tabular}{|c|c|c|c|c|c|}
\hline Fentanyl Analogue & $\begin{array}{l}\text { Patient } \\
\text { Demographic } \\
\text { (Gender, Age) }\end{array}$ & $\begin{array}{l}\text { Route of } \\
\text { Administration }\end{array}$ & Cause of Death & $\begin{array}{l}\text { Fentanyl Analogue } \\
\text { Concentration ( } \mathrm{ng} / \mathrm{mL}) \\
\text { from Specified Blood } \\
\text { Source }\end{array}$ & $\begin{array}{l}\text { Evidence of } \\
\text { Concomitant } \\
\text { Drugs }\end{array}$ \\
\hline \multirow[t]{8}{*}{ Cyclopropylfentanyl } & Male, 39 [20] & Inhalation & Mixed drug intoxication & Femoral: 19.8 & Yes \\
\hline & Male, 24 [22] & Unspecified & $\begin{array}{l}\text { Fentanyl analogue } \\
\text { overdose }\end{array}$ & Cardiac: present & No \\
\hline & Male, 25 [22] & Unspecified & Mixed drug intoxication & Cardiac: 14.0 & Yes \\
\hline & Male, 36 [26] & Unspecified & Mixed drug intoxication & Cardiac: 5.6 & Yes \\
\hline & Male, 27 [26] & Inhalation & Mixed drug intoxication & Cardiac: 5.6 & Yes \\
\hline & Male, 32 [26] & Intravenous & Mixed drug intoxication & Cardiac: 29.0 & Yes \\
\hline & Female, 19 [26] & Unspecified & Mixed drug intoxication & Cardiac: 82.0 & Yes \\
\hline & Male, 49 [26] & Unspecified & Mixed drug intoxication & Cardiac: 11.0 & Yes \\
\hline Furanylfentanyl & Male, 34 [32] & Intravenous & Mixed drug intoxication & Cardiac: 0.34 & Yes \\
\hline Tetrahydrofuranylfentanyl & Male, 3I [29] & Intravenous & Mixed drug intoxication & Source not specified: 339.0 & Yes \\
\hline
\end{tabular}

detected in the routine analysis due to low concentrations in the body because of their high potency and because not all laboratories have the technology to detect them, leading to potentially mass underreporting of fentanyl analoguerelated deaths worldwide. This may alter some conclusions drawn by this report. Furthermore, the quality of the included case series was variable. There was a lack of reporting of the clinical conditions of the decedents involved and there were missed opportunities to showcase statistical data to support their findings. Additionally, most studies did not explicitly state the route of administration involved in the fatalities, leading the authors of this review to deduce using their judgement. Therefore, the route of administration must be interpreted cautiously. Finally, unpublished reports have not been included in this review, excluding a valuable source of information.

\section{Implications for Practice and Further Research}

Forensic toxicological testing of opioid-involved deaths should be expanded to include fentanyl and fentanyl analogues. Increased efforts to educate the general public and healthcare professionals for the appropriate use of opioids and the recognition of tolerance and dependence should be encouraged and promoted. Where there is evidence of clear chronic drug abuse, all efforts should be used to encourage the individual to access treatment as these are the persons who are more likely to be adversely affected with fentanyl analogue use. This can be achieved by prescribing medications for opioid use disorders, such as opioid replacement agents (methadone, buprenorphine, levomethadyl) and/or opioid reversal agents (naloxone and naltrexone). ${ }^{45}$ Of the opioid reversal agents, naloxone is FDA approved for acute opioid overdoses whereas naltrexone is used for opioid use disorder with detoxification. Community distribution including takehome naloxone and mail order distribution programs are now in use internationally and such programs have shown to minimize opioid overdose-related deaths. ${ }^{46}$ Stricter national and local guidelines on opioid prescribing can also be implemented in areas where fatality incidents are particularly high. The regions, such as the US, where opioid-related deaths are still on rise despite the decline in opioid prescribing, other factors that might be contributing to the deaths must also be explored and addressed. Additionally, there should be tighter restrictions on the importation of chemicals at border entries as well as more funding for agents which operate to detect illicit synthesis of fentanyls and dismantle criminal drug networks. ${ }^{14}$ The availability of the fentanyl analogues identified in the studies included in this review are often restricted for use in non-humans or only available in specialized settings. For example, carfentanil which was responsible for overdose deaths in our included studies, is only licensed for use in 
elephants and other large mammals in the US. ${ }^{47}$ However, illicit manufacturing, import and distribution are key public health concerns. Patients with dual diagnoses of substance misuse and severe mental health are often likely to be at risk of harm from opioid misuse and deaths, and therefore additional consideration are needed from prevention and treatment perspectives. $^{48}$

\section{Conclusion}

The steady emergence of novel fentanyl analogues on the illicit drug market poses a global public health threat that is no longer localised to the US. This review shows that the majority of the decedents due to fentanyl analogues associated mortalities were in the United States and were young white males. Approximately, all deaths were unintentional and most used an intravenous route of administration. Novel fentanyl analogues cannot typically be identified using standard analytical methods since they usually have low active concentrations necessitating newer standard testing must be implemented. Overdose due to mixed drug toxicities with other opioids was a major cause of death. Therefore, education for healthcare professionals and patients is required on the appropriate use of prescription opioids and be taught to recognize signs of drug dependence.

\section{Ethical Publication Statement}

The authors confirm that they have read the journal's position on issues involved in ethical publication and affirm that this review is consistent with those guidelines.

\section{Funding}

This review did not receive any funding.

\section{Disclosure}

The authors have no conflicts of interest for this work to report.

\section{References}

1. Armenian P, Vo K, Barr-Walker J, Lynch K. Fentanyl, fentanyl analogs and novel synthetic opioids: a comprehensive review. Neuropharmacology. 2018;134:121-132. doi:10.1016/j. neuropharm.2017.10.016

2. Vardanyan R, Hruby V. Fentanyl-related compounds and derivatives: current status and future prospects for pharmaceutical applications. Future Med Chem. 2014;6(4):385-412. doi:10.4155/fmc.13.215

3. NICE Excellence. Alfentanil. BNF content published by NICE; 2020. Available from: https://bnf.nice.org.uk/drug/alfentanil.html. Accessed December 14, 2020.
4. NICE Excellence. Remifentanil. BNF content published by NICE; 2020. Available from: https://bnf.nice.org.uk/drug/remifentanil.html. Accessed December 14, 2020.

5. Sufentanil. Martindale: the complete drug reference; 2020. Available from: https://www-new-medicinescomplete-com.ezproxyd.bham.ac.uk/ \#/content/martindale/21077-g?hspl=sufentanil. Accessed December 14, 2020.

6. Alfentanil. Martindale: the complete drug reference. 2020. Available from: https://www-new-medicinescomplete-com.ezproxyd.bham.ac.uk/ \#/content/martindale/12339-b?hspl=Alfentanil. Accessed December 14, 2020.

7. Platt S, Raedle J. The opioid crisis in the USA: a public health emergency. Lancet. 2017;390(10107):2016.

8. DeWeerdt S. Tracing the US opioid crisis to its roots. Nature. 2019;573(7773):S10-S12. doi:10.1038/d41586-019-02686-2

9. Drug Policy Alliance. Drug Overdose; 2020. Available from: https:// drugpolicy.org/issues/drug-overdose. Accessed December 14, 2020.

10. Van Zee A. The promotion and marketing of oxycontin: commercial triumph, public health tragedy. Am J Public Health. 2009;99 (2):221-227. doi:10.2105/AJPH.2007.131714

11. Meier B. In guilty plea, oxycontin maker to pay $\$ 600$ million; 2007. Available from: https://www.nytimes.com/2007/05/10/business/ 11drug-web.html. Accessed December 14, 2020.

12. Prescription drugs: oxycontin abuse and diversion and efforts to address the problem. Washington, DC: General Accounting Office; December 2003. Publication GAO-04-110. Available from: gao.gov/ products/gao-04-110. Accessed December 13, 2020.

13. Tough P. The alchemy of oxyContin: from pain relief to drug addiction. New York Times Magazine; July 29 2001:37.

14. Advisory Council on the Misuse of Drugs. ACMD report - misuse of fentanyl and fentanyl analogues; 2020. London. Available from: https://assets.publishing.service.gov.uk/government/ uploads/system/uploads/attachment_data/file/855893/ACMD Report___Misuse_of_fentanyl_and_fentanyl_analogues.pdf. Accessed December 14, 2020.

15. National Institute on Drug Abuse. Overdose Death Rates; 2020. Available from: https://www.drugabuse.gov/drug-topics/trendsstatistics/overdose-death-rates. Accessed January 7, 2021.

16. Wilson N, Kariisa M, Seth P, et al. Drug and opioid-involved overdose deaths-United States, 2017-2018. MMWR Morb Mortal Wkly Rep. 2020;69(11):290-297. doi:10.15585/mmwr.mm6911a4

17. CDC Injury Center. Fentanyl. Drug Overdose; 2020. Available from: https://www.cdc.gov/drugoverdose/opioids/fentanyl.html. Accessed January 7, 2021.

18. Bulloch M. The evolution of the PDMP. Pharmacy Times; 2018. Available from: https://www.pharmacytimes.com/view/the-evolutionof-the-pdmp. Accessed July 26, 2021.

19. Issa M, Celestin J, Wasan AD. Issues associated with opioid use. In: Benzon HT, Rathmell JP, Wu CL, Turk DC, Argoff CE, Hurley RW, editors. Practical Management of Pain. 5th ed. Philadelphia:Mosby (Elsevier); 2014:683-694.

20. Tomassoni A, Hawk K, Jubanyik K, et al. Multiple fentanyl overdoses - New Haven, Connecticut, June 23, 2016. MMWR Morb Mortal Wkly Rep. 2017;66(4):107-111. doi:10.15585/ mm6604a4

21. Alenezi A, Yahyouche A, Paudyal V. Current status of opioid epidemic in the United Kingdom and strategies for treatment optimisation in chronic pain chronic non-malignant pain. Int J Clin Pharm. 2021;43(2):318-322. doi:10.1007/s11096-020-01205-y

22. Alenezi A, Yahyouche A, Paudyal V. Interventions to optimise prescribed medicines and reduce their misuse in chronic non-malignant pain: a systematic review. Eur J Clin Pharmacol. 2021;77 (4):467-490. doi:10.1007/s00228-020-03026-4

23. European Monitoring Centre for Drugs and Drug Addiction. European drug report 2019: trends and developments. Luxembourg: Publications Office of the European Union; 2019. 
24. O'Donnell J, Halpin J, Mattson C, Goldberger B, Gladden R. Deaths involving fentanyl, fentanyl analogs, and U-47700 - 10 States, JulyDecember 2016. MMWR Morb Mortal Wkly Rep. 2017;66 (43):1197-1202. doi:10.15585/mmwr.mm6643e1

25. Cheema E, McGuinness K, Hadi MA, et al. Causes, nature and toxicology of fentanyl-associated deaths: a systematic review of deaths reported in peer-reviewed literature. $J$ Pain Res. 2020;13:3281-3294. doi:10.2147/JPR.S280462

26. Joannabriggs-webdev.org. Critical appraisal tools - JBI; (n.d.). Available from: https://joannabriggs.org/critical-appraisal-tools. Accessed December 14, 2020.

27. Brockbals L, Staeheli S, Gentile S, et al. Fatal poisoning involving cyclopropylfentanyl - investigation of time-dependent postmortem redistribution. Forensic Sci Int. 2019;294:80-85. doi:10.1016/j. forsciint.2018.11.007

28. Butler D, Shanks K, Behonick G, Smith D, Presnell S, Tormos L. Three cases of fatal acrylfentanyl toxicity in the United States and a review of literature. $J$ Anal Toxicol. 2017;42(1):e6-e11. doi:10.1093/jat/bkx083

29. Castellino C, Van Cleve D, Cabrera R. Two cyclopropyl fentanyl case studies in Los Angeles. J Anal Toxicol. 2021;45(1):105-109. doi:10.1093/jat/bkaa037

30. Corsi NJ, Dragovic LJ. Fatal overdoses involving carfentanil: a case series. J Forensic Sci Med. 2019;5(3):147. doi:10.4103/jfsm. jfsm_74_17

31. Daniulaityte R, Juhascik MP, Strayer KE, et al. Overdose deaths related to fentanyl and its analogs - Ohio, January-February 2017. MMWR Morb Mortal Wkly Rep. 2017;66(34):904-908. doi:10.15585/ mmwr.mm6634a3

32. Elliott S, Hernandez Lopez E. A series of deaths involving carfentanil in the UK and associated post-mortem blood concentrations. $J$ Anal Toxicol. 2018;42(4):e41-e45. doi:10.1093/jat/bkx109

33. Fagiola M, Hahn T, Avella J. Five postmortem case reports with qualitative analysis of cyclopropylfentanyl by LC-MS-MS. $J$ Anal Toxicol. 2018;43(4):e1-e6. doi:10.1093/jat/bky094

34. Gaulier J, Richeval C, Phanithavong M, et al. A case report of carfentanil-related fatality in France. Toxicol Anal Clin. 2019;31 (4):323-331. doi:10.1016/j.toxac.2019.01.002

35. Hikin L, Smith P, Ringland E, Hudson S, Morley S. Multiple fatalities in the North of England associated with synthetic fentanyl analogue exposure: detection and quantitation a case series from early 2017. Forensic Sci Int. 2018;282:179-183. doi:10.1016/j. forsciint.2017.11.036

36. Krotulski A, Papsun D, Friscia M, et al. Fatality following ingestion of tetrahydrofuranylfentanyl, U-49900 and methoxy-phencyclidine. $J$ Anal Toxicol. 2017;42(3):e27-e32. doi:10.1093/jat/bkx092
37. Moss D, Brown D, Douglas B. An acetyl fentanyl death in Western Australia. Aust J Forensic Sci. 2017;51(1):73-77. doi:10.1080/ 00450618.2017.1315836

38. Shanks K, Behonick G. Detection of carfentanil by LC-MS-MS and reports of associated fatalities in the USA. $J$ Anal Toxicol. 2017;41 (6):466-472. doi:10.1093/jat/bkx042

39. Swanson D, Hair L, Strauch Rivers S, et al. Fatalities involving carfentanil and furanyl fentanyl: two case reports. $J$ Anal Toxicol. 2017;41(6):498-502. doi:10.1093/jat/bkx037

40. Concheiro M, Chesser R, Pardi J, Cooper G. Postmortem toxicology of new synthetic opioids. Front Pharmacol. 2018;9:1210. doi:10.3389/fphar.2018.01210

41. Drug Safety Update. Benzodiazepines and opioids: reminder of risk of potentially fatal respiratory depression. MHRA. 2020;13(8):5.

42. Drug Safety Update. Pregabalin (Lyrica), gabapentin (Neurontin) and risk of abuse and dependence: new scheduling requirements from 1 April. MHRA. 2019;12(9):4.

43. Marchei E, Pacifici R, Mannocchi G, Marinelli E, Busardò F, Pichini S. New synthetic opioids in biological and non-biological matrices: a review of current analytical methods. Trends Analyt Chem. 2018;102:1-15. doi:10.1016/j.trac.2018.01.007

44. European Monitoring Centre for Drugs and Drug Addiction. Drugrelated deaths and mortality in Europe. Luxembourg: Publications Office of the European Union; 2019.

45. Substance Abuse and Mental Health Services Administration. Medications for opioids use disorder. Treatment improvement protocol 63; 2020. Available from: https://store.samhsa.gov/sites/default/ files/SAMHSA_Digital_Download/PEP20-02-01-006_508.pdf. Accessed June 14, 2021.

46. European Monitoring Centre for Drugs and Drug Addiction. Takehome naloxone; (n.d.). Available from: https://www.emcdda.europa. eu/publications/topic-overviews/take-home-naloxone_en\#. Accessed 26 July 2021.

47. Bettinger JJ, Trotta ND, Fudin J, Wegrzyn EL, Schatman ME. Fentanyl: separating fact from fiction. Pract Pain Manag. 2019;18 (5). Available from: www.practicalpainmanagement.com/treatments/ pharmacological/opioids/fentanyl-separating-fact-fiction.

48. Alsuhaibani R, Smith D, Lowrie R, Aljhani S, Paudyal V. Scope, quality and inclusivity of international clinical guidelines on mental health and substance abuse in relation to dual diagnosis, social and community outcomes: a systematic review. BMC Psychiatry. 2021;21 (1):1-23. doi:10.1186/s12888-021-03188-0
Journal of Pain Research

\section{Publish your work in this journal}

The Journal of Pain Research is an international, peer reviewed, open access, online journal that welcomes laboratory and clinical findings in the fields of pain research and the prevention and management of pain. Original research, reviews, symposium reports, hypothesis formation and commentaries are all considered for publication. The manuscript management system is completely online and includes a very quick and fair peer-review system, which is all easy to use. Visit http:// www.dovepress.com/testimonials.php to read real quotes from published authors. 